\section{Transformation of the Nitrogen Cycle: Recent Trends, Questions, and Potential Solutions}

\author{
James N. Galloway, ${ }^{1 *}$ Alan R. Townsend, ${ }^{2}$ Jan Willem Erisman, ${ }^{3}$ Mateete Bekunda, ${ }^{4}$ \\ Zucong Cai, ${ }^{5}$ John R. Freney, ${ }^{6}$ Luiz A. Martinelli, ${ }^{7}$ Sybil P. Seitzinger, ${ }^{8}$ Mark A. Sutton ${ }^{9}$
}

Humans continue to transform the global nitrogen cycle at a record pace, reflecting an increased combustion of fossil fuels, growing demand for nitrogen in agriculture and industry, and pervasive inefficiencies in its use. Much anthropogenic nitrogen is lost to air, water, and land to cause a cascade of environmental and human health problems. Simultaneously, food production in some parts of the world is nitrogen-deficient, highlighting inequities in the distribution of nitrogencontaining fertilizers. Optimizing the need for a key human resource while minimizing its negative consequences requires an integrated interdisciplinary approach and the development of strategies to decrease nitrogen-containing waste.

$\mathrm{O}$ ur understanding of reactive nitrogen (Nr) (1) and the $\mathrm{N}$ cycle has shifted from how to promote food production to a realization that agricultural intensification damages environmental systems (2). Since 1970, world population has increased by $78 \%$ and reactive nitrogen creation has increased by $120 \%$ In 1970, Delwiche stated, "The ingenuity that has been used to feed a growing world population will have to be matched quickly by an effort to keep the nitrogen cycle in reasonable balance" (3). Thirty-five years later, Dobermann and Cassman pointed out, "Failure to arrest the decrease in cereal crop area and to improve nitrogen use efficiency in the world's most important agricultural systems will likely cause severe damage to environmental services at local, regional, and global scales due to a large increase in reactive $\mathrm{N}$ load in the environment (4)."

It is clear that an optimum has not been achieved. In some parts of the world, $\mathrm{Nr}$ has been used to create an excess of food and a growing prevalence of unhealthy diets, while also con-

${ }^{1}$ Environmental Sciences Department, University of Virginia, Charlottesville, VA 22904, USA. ${ }^{2}$ Institute of Arctic and Alpine Research and Department of Ecology and Evolutionary Biology, Campus Box 450, University of Colorado, Boulder, CO 80309, USA. ${ }^{3}$ Energy Research Centre of the Netherlands, ECN, Post Office Box 1, 1755 ZG Petten, Netherlands. ${ }^{4}$ Faculty of Agriculture, Makerere University, Post Office Box 7062, Kampala, Uganda. ${ }^{5}$ Institute of Soil Science, Chinese Academy of Sciences, Nanjing 210008, China. ${ }^{6}$ Commonwealth Scientific and Industrial Research Organisation Plant Industry, GPO Box 1600, Canberra, A.C.T., Australia. ${ }^{7}$ Centro de Energia Nuclear na Agricultura-Universidade de São Paulo, Avenida Centenario, 303, Piracicaba-SP, Brazil. ${ }^{8}$ Rutgers, The State University of New Jersey, Institute of Marine and Coastal Sciences, Rutgers/National Oceanic and Atmospheric Administration Cooperative Marine Education and Research Program, New Brunswick, N] 08901, USA. ${ }^{9}$ Centre for Ecology and Hydrology, Edinburgh Research Station, Bush Estate, Penicuik, Midlothian, EH26 0QB, UK.

*To whom correspondence should be sent. E-mail: jng@ virginia.edu tributing to a host of environmental problems $(2,5-7)$. Yet, other world regions lack sufficient $\mathrm{Nr}$ to meet even the most basic caloric demands of hundreds of millions of people (8).

Major research and management challenges remain and are becoming ever more pressing as the creation and use of $\mathrm{Nr}$ continues to accelerate. Although diverse management strategies are necessary, they are also possible, and we believe a more favorable balance between the benefits and unwanted consequences of $\mathrm{Nr}$ can be achieved.

\section{Continued Acceleration of $\mathrm{Nr}$ Creation}

$\mathrm{Nr}$ creation continues to increase every year. It is dominated by agricultural activities, but fossil fuel energy plays an important role, and the growing prevalence of biofuels is adding a new and rapidly changing dimension. From 1860 to 1995, energy and food production increased steadily on both an absolute and per capita in 1860 to $156 \mathrm{Tg} \mathrm{N}$ in 1995. The change was enormous, and it increased further from $156 \mathrm{Tg}$ $\mathrm{N} \mathrm{yr}^{-1}$ in 1995 to $187 \mathrm{Tg} \mathrm{N} \mathrm{yr}^{-1}$ in 2005 , in large part because cereal production increased from 1897 to 2270 million tons (20\%), and meat production increased from 207 to 260 million tons (26\%) (9). These rising agricultural demands were sustained by a rise in $\mathrm{Nr}$ creation by the Haber-Bosch process from $100 \mathrm{Tg} \mathrm{N}$ $\mathrm{yr}^{-1}$ to $121 \mathrm{Tg} \mathrm{N} \mathrm{yr}^{-1}$ (20\%) (9). Cultivationinduced biological nitrogen fixation (C-BNF) occurs in several agricultural systems, with crop, pasture, and fodder legumes being the most important (10). The C-BNF estimate for 1995 was 31.5 $\mathrm{Tg} \mathrm{N} \mathrm{(5)} \mathrm{and,} \mathrm{because} \mathrm{of} \mathrm{the} \mathrm{increase} \mathrm{in}$ soybean and meat production over the past decade, we estimate that in $2005 \mathrm{C}$-BNF was $40 \mathrm{Tg} \mathrm{N}$. There is substantial uncertainty in this value, and this is a critical area where more precise data are needed. In parallel, primary basis; Nr creation also increased from $\sim 15 \mathrm{Tg} \mathrm{N}$ commercial energy production by coal, natural gas, and petroleum combustion increased from 8543 million tons of oil equivalents (mtoe) to 10,600 mtoe $(24 \%)$, much of it in the developing world (11). However, decreases in NOx emissions in the developed world, among other reasons, led to a relatively constant global creation rate of $\mathrm{Nr}-\mathrm{NOx}$ of $\sim 25 \mathrm{Tg} \mathrm{N} \mathrm{yr}^{-1}$ from 1995 to 2000 (12), and we assume for the purpose of discussion that this value also holds for 2005 .

Finally, an important but poorly understood aspect of $\mathrm{N}$ mobilization is industrial $\mathrm{Nr}$ use. $\mathrm{NH}_{3}$ from the Haber-Bosch process is used as a raw material to create multiple products, including nylon, plastics, resins, glues, melamine, animal/fish/shrimp feed supplements, and explosives. In 2005, $\sim 23 \mathrm{Tg} \mathrm{N}$ was used for chemical production (13), accounting for $20 \%$ of HaberBosch $\mathrm{Nr}$, but little is known about the fate of $\mathrm{Nr}$ used in these industrial activities.

\section{Nr Distribution Patterns Are Changing}

In $2004, \sim 45 \mathrm{Tg} \mathrm{N}$ of the $\sim 187 \mathrm{Tg} \mathrm{N}$ of $\mathrm{Nr}$ created was traded internationally (Fig. 1), and in the preceding decade, global trade of $\mathrm{N}$ commodities increased twice as fast as the rate of $\mathrm{Nr}$ creation. Unlike aquatic or atmospheric transport, where $\mathrm{Nr}$ is diluted to varying degrees, commerce typically results in injection of $\mathrm{Nr}$ to ecosystems in more concentrated doses. Although this has the potential to cause greater damage to a smaller region, it also allows the possibility of greater control over $\mathrm{Nr}$ release. However, the rise in international trade is posing new socioeconomic questions, such as who pays for environmental damage associated with $\mathrm{Nr}$ losses (14). Regions that consume N-containing products, such as meat and milk, may be far removed from regions that produce the commodity and thus do not have to bear the environmental cost of the production. For example, in 1910, The Netherlands used $13 \mathrm{k}$ tonne of fertilizer $\mathrm{N} \mathrm{yr}^{-1}$ to produce food for its population of 6 million. In 1999, for the same agricultural area, $400 \mathrm{k}$ tonne $\mathrm{N} \mathrm{yr}^{-1}$ fertilizer $\mathrm{N}$ was used, and the yields were enough to feed 32 million people, only half of whom lived in The Netherlands. The rest of the food, and the Nr it contained, was exported, whereas the $\mathrm{N}$ lost in the food-production process remained in the Dutch environment, causing increased groundwater pollution, ambient ammonia and particle emissions, and nitrogen deposition (15). Similarly, areas of Latin America are bearing the cost of land conversion for soy that is fueling rising meat consumption in Asia (14).

On a global basis, atmospheric transport and subsequent deposition has become the dominant $\mathrm{Nr}$ distribution process. It is estimated that in 1860, $34 \mathrm{Tg} \mathrm{N} \mathrm{yr}^{-1}$ of $\mathrm{Nr}$ was emitted as NOx and $\mathrm{NH}_{3}$ and then deposited to the Earth's surface as NOy and NHx; in 1995, it had increased to $100 \mathrm{Tg} \mathrm{N} \mathrm{yr}{ }^{-1}$; by 2050 , it is projected to be $200 \mathrm{Tg} \mathrm{N} \mathrm{yr}^{-1}$ (5). $\mathrm{N}$ deposition to ecosystems in the absence of human influence is generally 


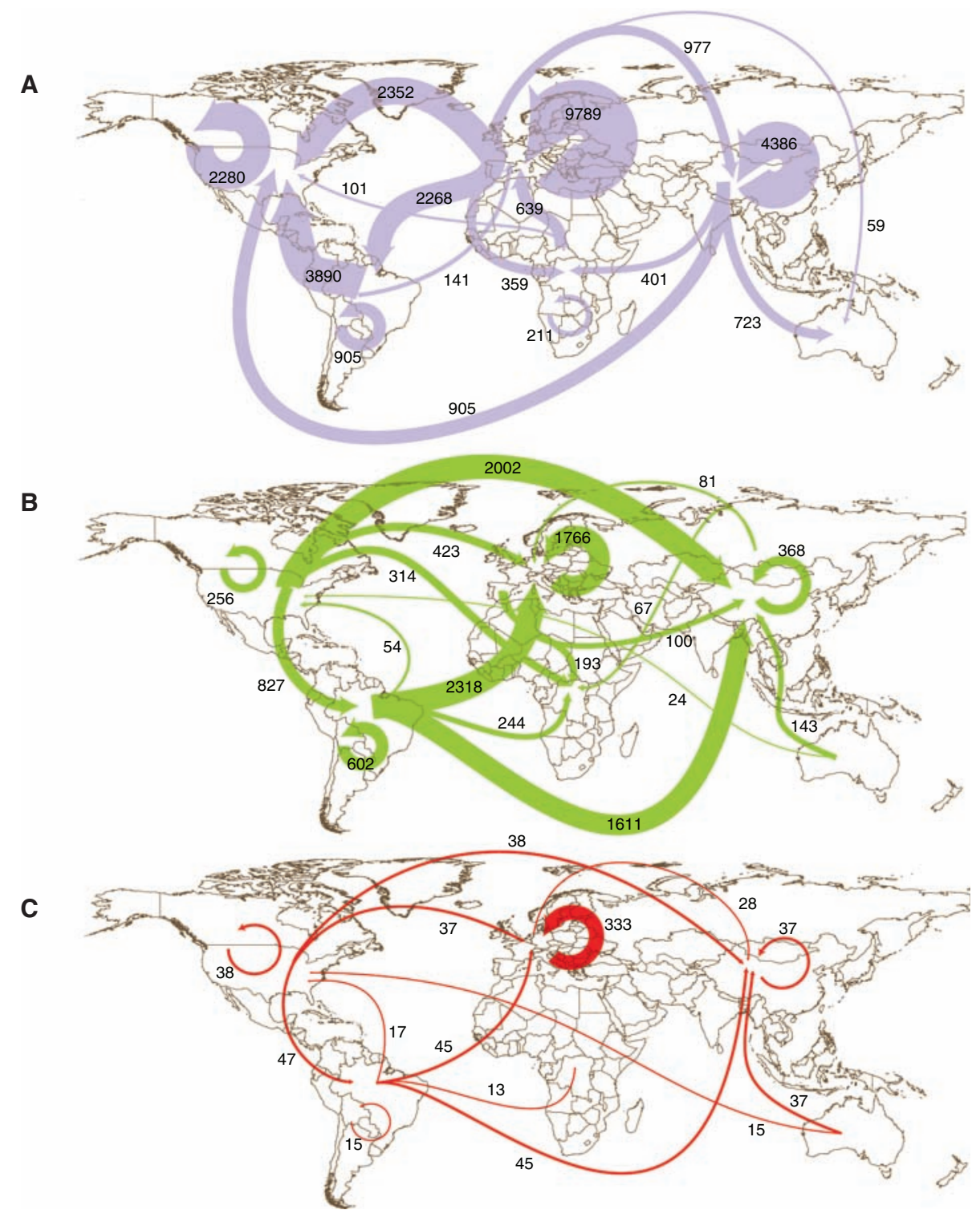

Fig. 1. $N$ contained in internationally traded (A) fertilizer $(31 \mathrm{Tg} \mathrm{N}),(B)$ grain $(12 \mathrm{Tg} \mathrm{N})$, and $(\mathbf{C})$ meat $(0.8 \mathrm{Tg} \mathrm{N})$. Data are for 2004 and are in units of thousand of tons. Minimum requirements for drawing a line are 50,000 tons N, 20,000 tons N, and 10,000 tons N for fertilizer, grain, and meat, respectively (42).

$\sim 0.5 \mathrm{~kg} \mathrm{~N} \mathrm{ha}^{-1} \mathrm{yr}^{-1}$ or less (16). There are now large regions of the world where average $\mathrm{N}$ deposition rates exceed $10 \mathrm{~kg} \mathrm{~N} \mathrm{ha}^{-1} \mathrm{yr}^{-1}$, greater than an order of magnitude increase compared with natural rates. By 2050, this may double, with

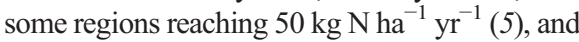
landscape-level inputs may be much larger, especially for forest ecosystems (17). These rates are well in excess of the critical loads that have detrimental impacts on receiving ecosystems (18) (Fig. 2). Critical loads for the open ocean have not been calculated, but Duce et al. (19) conclude that the increasing amounts of atmospheric anthropogenic $\mathrm{Nr}$ entering the ocean could increase annual new marine biological production by $\sim 3 \%$ and increase the emission of $\mathrm{N}_{2} \mathrm{O}$ to the atmosphere by $\sim 1.6 \mathrm{Tg} \mathrm{N} \mathrm{yr}^{-1}$.

Given the growing importance of the atmosphere in $\mathrm{Nr}$ distribution, it is critical to get a better understanding of emissions rates. There is a relatively good understanding of NOx emissions from fossil fuel combustion, but less so from biomass burning and soil emissions. The largest uncertainties are in the $\mathrm{NH}_{3}$ emissions rates, from all sources, on all scales (17). There are also critical questions about the fate and impact of the $\mathrm{N}$ deposited to terrestrial, freshwater, and marine realms.

\section{Vexing Questions}

$\mathrm{Nr}$ creation is still accelerating, a trend unlikely to change in the near future. The additional anthropogenic $\mathrm{Nr}$ affects climate, the chemistry of the atmosphere, and the composition and function of terrestrial and aquatic ecosystems (2). Moreover, because a single molecule of reactive $\mathrm{N}$ can "cascade" through the environment, it can contribute to more than one of these environ- mental responses (20). Yet, we also know that $\mathrm{Nr}$ creation is essential to support a burgeoning human population (21) and that hundreds of millions of people still suffer from a "fertilizer deficit" (8). Finally, we know that environmental changes wrought by excess $\mathrm{Nr}$ can feed back to affect human health and welfare, both directly, for example through increased production of atmospheric particulate matter, and indirectly through impacts on food production (6). Thus, the grandest overall challenge posed by a changing $\mathrm{N}$ cycle is how to maximize the benefits of anthropogenic $\mathrm{Nr}$ while minimizing its unwanted consequences (see www.initrogen.org).

Although the role of $\mathrm{Nr}$ in multiple aspects of environmental change is undeniable, important research questions remain unresolved. We have identified five broad categories of questions that are priorities for future research.

What is the ultimate fate of $\mathrm{Nr}$ ? Although data on the creation of anthropogenic $\mathrm{Nr}$ are relatively well constrained, those on its fate are uncertain. For example, in the mid-1990s, the fate of only $35 \%$ of $\mathrm{Nr}$ inputs to the terrestrial biosphere was relatively well known: $18 \%$ was exported to and denitrified in coastal ecosystems, $13 \%$ was deposited to the ocean via the marine atmosphere, and $4 \%$ was emitted as $\mathrm{N}_{2} \mathrm{O}$ (5). Thus, the majority (65\%) either accumulated in soils, vegetation, and groundwater or was denitrified to dinitrogen $\left(\mathrm{N}_{2}\right)$, but the uncertainty of those estimates remains large at every scale.

Even with these uncertainties, it is likely that denitrification is an important $\mathrm{Nr}$ sink. The first spatially explicit pattern of denitrification from soils to the coastal ocean suggested that more than $80 \%$ of denitrification is occurring in soils and freshwater systems (groundwater, rivers, lakes, and reservoirs). The bulk of the remainder $(\sim 15 \%)$ appears to occur in continental shelf sediments, thus indicating that rivers, although important sources to coastal systems, are typically small sources of $\mathrm{Nr}$ to the open ocean, even in heavily altered regions (22).

There is a growing database on $\mathrm{Nr}$ riverine fluxes, and several models are available that relate watershed characteristics to $\mathrm{Nr}$ flux $(23,24)$. Even with these advances, some of the largest uncertainties in measuring denitrification rates are in upland terrestrial systems, which seem to account for a considerable, but unknown, $\mathrm{Nr}$ "sink." $\mathrm{Nr}$ inputs to these systems continue to rise, however, so the question is whether the fraction of $\mathrm{N}$ exported to the coasts will remain small or whether upland "sinks" will saturate to allow greater $\mathrm{N}$-fueled coastal change.

Rising levels of atmospheric deposition also lend urgency to multiple questions about the fate of Nr. Ultimately, the fate of $\mathrm{Nr}$ that enters terrestrial systems appears to be under strong climatic control (25), an interaction that helps explain regional differences in $\mathrm{N}$ export and that should be considered in forecasts of future $\mathrm{N}$ cycle dynamics. The fate and impacts of $\mathrm{Nr}$ are also often dependent on its chemical form, 
further highlighting the need to better resolve changing inputs of oxidized versus reduced forms of $\mathrm{Nr}$.

What are the net climate effects of increasing $\mathrm{Nr}$ ? Nitrogen is both influenced by and affects climate; the net contributions of anthropogenic $\mathrm{Nr}$ to a changing climate remain widely debated $(17,26)$. Nr can directly increase radiative forcing in the troposphere, principally through the production of $\mathrm{N}_{2} \mathrm{O}$ and tropospheric $\mathrm{O}_{3}$, but atmospheric $\mathrm{Nr}$ can also have cooling effects (26), largely through tropospheric aerosols and stratospheric $\mathrm{O}_{3}$ declines. Moreover, $\mathrm{Nr}$ has strong interactions with the carbon (C) cycle that can have global-scale effects on atmospheric carbon dioxide $\left(\mathrm{CO}_{2}\right)$ and methane $\left(\mathrm{CH}_{4}\right)(27,28)$.

Elevated $\mathrm{N}$ deposition may stimulate plant growth in N-limited regions and cause substantial $\mathrm{CO}_{2}$ uptake in Northern Hemisphere forests, although the size is controversial (see SOM text). $\mathrm{N}$-driven $\mathrm{C}$ storage in nonforested or agricultural systems appears modest at best, and $\mathrm{N}$-fueled ics are also home to the bulk of the planet's terrestrial and freshwater biodiversity. Given that elevated $\mathrm{Nr}$ inputs are known to drive biodiversity losses in higher latitude ecosystems (32), the projected trends in tropical regions are cause for concern (33).

Most biological $\mathrm{N}$ fixation in terrestrial systems occurs in tropical regions; this, combined with the widespread existence of phosphorus- and cation-deficient soils causes many tropical ecosystems to exist in a relatively N-rich state (34). Thus, at least in theory, the response of these systems to additional $\mathrm{N}$ inputs could be very different from those of temperate ecosystems and could result in rapid $\mathrm{N}$ losses to air and water, soil cation depletion, and reduced $\mathrm{C}$ uptake (34). Yet, data on such ecosystem responses and their translation into effects on community structure and biodiversity loss remain notably rare.

How does $\mathrm{Nr}$ affect human health? The ability to fix $\mathrm{N}$ on large scales is unquestionably a boon to humanity. Perhaps $40 \%$ of the

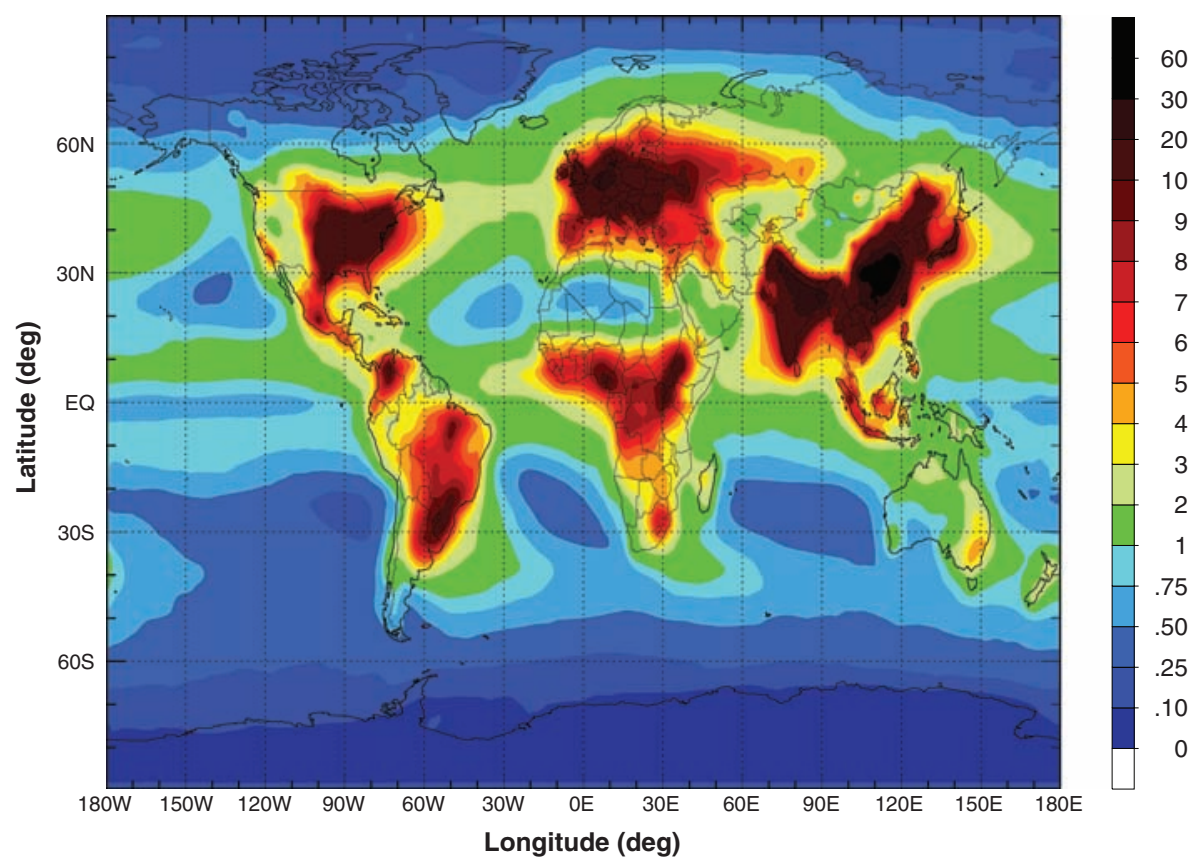

Fig. 2. Estimated $\mathrm{N}$ deposition from global total $\mathrm{N}$ ( $\mathrm{NOy}$ and $\mathrm{NHx}$ ) emissions, totaling $105 \mathrm{Tg} \mathrm{N} \mathrm{y^{-1 }}$. The unit scale is $\mathrm{kg} \mathrm{N} \mathrm{ha}^{-1} \mathrm{y}^{-1}$, modified from the original units $\left(\mathrm{mg} \mathrm{m}^{-2} \mathrm{y}^{-1}\right)$ (16).

increases in tropospheric $\mathrm{O}_{3}$ can reduce $\mathrm{C}$ uptake in all systems (29). It remains a major research challenge to quantify all relevant $\mathrm{N}$ interactions sufficiently to estimate the net effect of $\mathrm{Nr}$ on climate forcing $(17,26)$.

How will tropical regions respond to rising $N$ inputs? Much of our knowledge on $\mathrm{N}$ dynamics is from the temperate world, yet tropical regions will receive the most dramatic increases in $\mathrm{Nr}$ inputs over the next few decades [see, e.g., (30)]. Some tropical regions already experience elevated $\mathrm{N}$ deposition, acidic deposition, and aquatic eutrophication (31), both from urban development and from a combination of agricultural extensification and intensification. The trop- world's dietary protein now comes from synthetic fertilizers, and estimates suggest that at least 2 billion people would not be alive today without the modern manifestations of the Haber-Bosch process (21). Yet, in many developed nations, the products from $\mathrm{N}$-intensive agricultural practices lead to unhealthy diets, whereas elsewhere a lack of synthetic fertilizers, combined with depleted soil nutrient reserves, directly contributes to widespread malnutrition (6).

Once $\mathrm{Nr}$ enters the environment, its effects on terrestrial, aquatic, and atmospheric realms can influence human health and welfare in several ways. For example, N-driven increases in tropospheric $\mathrm{O}_{3}$ pose direct health threats to humans and cause substantial losses in agricultural productivity (35). Nitric oxide and ammonia emissions fuel fine-particle and tropospheric $\mathrm{O}_{3}$ formation, which exacerbate pulmonary disease (6). The health consequences of drinking water with elevated nitrate levels, including cancer and reproductive risks, remain poorly known but are important to resolve (36). Excess $\mathrm{N}$ in the environment may also change the prevalence of important infectious diseases, including malaria, West Nile virus, cholera, and schistosomiasis (37). Yet, in some regions with heavy infectious disease burdens, $\mathrm{Nr}$ is needed for adequate nutrition to mount effective immune responses to infection. As countries industrialized during the past century, improved nutrition alone reduced the threat from infectious diseases (6).

How will biofuel development alter the $N$ cycle? The rapid development of biofuels has created an entirely new link between human activities and the global $\mathrm{N}$ cycle, but the full suite of connections is not well resolved. Currently, much of the world's biofuels are produced from corn in the United States or sugar cane in Brazil. U.S. corn covers nearly 29 million ha and is fertilized by an average of $160 \mathrm{~kg} \mathrm{~N} \mathrm{ha}^{-1} \mathrm{yr}^{-1}$; Brazilian cane covers $\sim 7$ million ha and receives an average of $100 \mathrm{~kg} \mathrm{~N} \mathrm{ha}^{-1} \mathrm{yr}^{-1}$. As with many intensive agricultural systems, $\mathrm{N}$ fertilizer use efficiency in Brazilian sugar cane is low: Only $\sim 30 \%$ ends up in plant tissues (38). Thus, most of the applied $\mathrm{N}$ reaches the environment, and because the sugar cane area is predicted to double in Brazil by 2016, the biofuel industry will contribute to a rapidly changing tropical $\mathrm{N}$ cycle (38). Consequently, $\mathrm{N}$-intensive biofuels could cancel out any $\mathrm{CO}_{2}$ savings by contributing to both $\mathrm{N}_{2} \mathrm{O}$ and tropospheric $\mathrm{O}_{3}$ production (39). Second-generation biofuels will use more woody biomass from year-round crops and production forests and tend to have much higher conversion efficiencies. Although the full environmental consequences of these systems are also not well understood, their required $\mathrm{N}$ use should be smaller than that of current first-generation crops.

\section{A Strategy for Now}

There is compelling evidence that human alteration of the $\mathrm{N}$ cycle is negatively affecting human and ecosystem health. As demands for food and energy continue to increase, both the amount of $\mathrm{Nr}$ created and the magnitude of the consequences will also increase. Given the complexities of $\mathrm{Nr}$ use, its environmental mobility, and differences among regions, no single strategy will suffice (40). However, in keeping with the Nanjing Declaration on Nitrogen Management (41), here we highlight the intervention points in the global $\mathrm{N}$ cycle where $\mathrm{N}$ flows are concentrated and should be easiest to target (Fig. 3). We also give rough estimates of the decreases in $\mathrm{Nr}$ use or loss to the environment that are possible to achieve once the suggested strategies are implemented.

Although we realize that the implementation will take time, the estimates are what might 


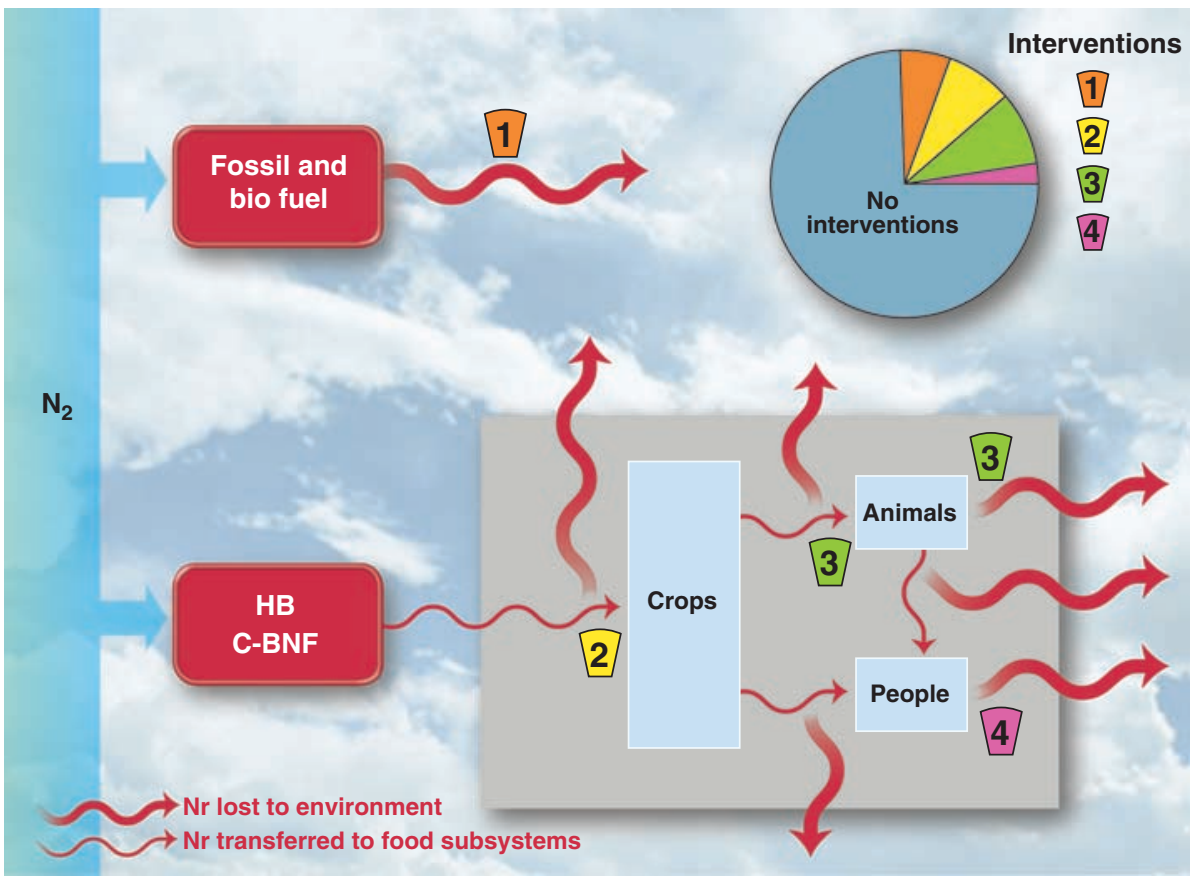

Fig. 3. Conceptual model of where interventions in the $\mathrm{N}$ cycle can be used to decrease the amount of $\mathrm{Nr}$ created or the amount of $\mathrm{Nr}$ lost to the environment. The red boxes represent subsystems where $\mathrm{Nr}$ is created. The sky-background space represents the environment. Arrows leaving the red boxes either result in $\mathrm{Nr}$ lost to environment (fossil fuel and biofuel combustion) or inputs to the food production system (gray box). The light blue boxes within the gray box represent subsystems within the food production system where $\mathrm{Nr}$ is used. $\mathrm{Nr}$ can either enter these subsystems (thin red lines), or be lost to the environment (thick red lines). The numbers represent intervention points for $\mathrm{N}$ management. The pie chart shows the magnitude of $\mathrm{Nr}$ managed by the four interventions relative to the total amount created (187 Tg N) in 2005.

reasonably be expected to occur with current technology (see SOM text). First, controlling NOx emissions from fossil-fuel combustion using maximum feasible reductions would result in a decrease of $\mathrm{Nr}$ creation from $25 \mathrm{Tg} \mathrm{N} \mathrm{yr}^{-1}$ to $7 \mathrm{Tg} \mathrm{N} \mathrm{yr}^{-1}$. Second, increasing nitrogen-uptake efficiency of crops would decrease $\mathrm{Nr}$ creation by about $15 \mathrm{Tg} \mathrm{N} \mathrm{yr}^{-1}$. Third, improved animalmanagement strategies would decrease $\mathrm{Nr}$ creation by about $\sim 15 \mathrm{Tg} \mathrm{N} \mathrm{yr}^{-1}$. Fourth, even if only half the 3.2 billion people living in cities had access to sewage treatment, $5 \mathrm{Tg} \mathrm{N} \mathrm{yr}^{-1}$ could be converted to $\mathrm{N}_{2}$.

Together, these interventions represent a potential decrease of $\sim 53 \mathrm{Tg} \mathrm{N} \mathrm{yr}^{-1}$ created per year, or $\sim 28 \%$ of the total $\mathrm{Nr}$ created in 2005 . With this reduction, we would be able to largely offset the increases in $\mathrm{Nr}$ losses required for future growth in food, feed, fuel, and fiber production and energy use. Other intervention points are clearly needed if $\mathrm{Nr}$ creation rates are to decrease in the future. Although these estimates are necessarily rough, and implementing them would not be trivial, they indicate that a multipronged, integrated approach can decrease the amount of $\mathrm{Nr}$ lost to the environment.

Multiple comprehensive analyses of management strategies for some or all of these points have been made in recent years. Common to nearly all such analyses is a clear message that no single strategy will work.
We conclude by stressing two points. First, although reducing $\mathrm{Nr}$ creation and its unwanted impacts will be challenging, it is both possible and of critical importance. Second, not all management priorities are about reduction of Nr. Substantial and sustained intervention is also needed in regions that do not have sufficient $\mathrm{Nr}$ or other nutrients to sustain the population (8). In such regions, it will be important to seek ways to increase food production while minimizing nutrient loss and its subsequent environmental damages.

\section{References and Notes}

1. The term reactive nitrogen $(\mathrm{Nr})$ as used in this paper includes all biologically active, photochemically reactive, and radiatively active $\mathrm{N}$ compounds in the atmosphere and biosphere of Earth. Thus, $\mathrm{Nr}$ includes inorganic reduced forms of $\mathrm{N}$ (e.g., $\mathrm{NH}_{3}$ and $\mathrm{NH}_{4}{ }^{+}$), inorganic oxidized forms (e.g., $\mathrm{NOx}, \mathrm{HNO}_{3}, \mathrm{~N}_{2} \mathrm{O}$, and $\mathrm{NO}_{3}^{-}$), and organic compounds (e.g., urea, amines, and proteins), by contrast to unreactive $\mathrm{N}_{2}$ gas.

2. P. M. Vitousek et al., Ecol. Appl. 7, 737 (1997).

3. C. C. Delwiche, Sci. Am. 223, 137 (1970).

4. A. Dobermann, K. G. Cassman, Sci. China C Life Sci. 48, 745 (2005) (Special Issue).

5. J. N. Galloway et al., Biogeochemistry 70, 153 (2004).

6. A. R. Townsend et al., Front. Ecol. Environ. 1, 240 (2003).

7. X. Jin, Q. Xu, C. Huang, Sci. China C Life Sci. 48, 948 (2005).

8. P. A. Sanchez, M. S. Swaminathan, Lancet 365, 442 (2005).

9. Food and Agriculture Organization, FAO statistical databases (2006), Rome, available at http://faostat. fao.org/default.aspx.

10. V. Smil, Global Biogeochem. Cycles 13, 647 (1999).

11. BP Global, Statistical Review of World Energy 2007 (available at www.bp.com/productlanding.do? categoryld=6848\& contentld=7033471)
12. J. Cofala et al., Atmos. Environ. 41, 8486 (2007).

13. M. Prud'homme, Global Fertilizers and Raw Materials Supply and Supply/Demand Balances (International Fertilizer Industry Association, Istanbul, 2007), pp. 2007-2011.

14. R. Naylor et al., Science 310, 1621 (2005).

15. J. W. Erisman et al., Sci. China C Life Sci. 48, 827 (2005).

16. F. Dentener et al., Global Biogeochem. Cycles 20, GB4003 (2006)

17. M. A. Sutton et al., Environ. Pollut. 150, 125 (2007).

18. B. Achermann, R. Bobbink, Eds., Empirical Critical Loads for Nitrogen. Environmental Documentation No. 164 (Swiss Agency for the Environment, Forests, and Landscape, Berne, 2003).

19. R. A. Duce et al., Science 320, 893 (2008).

20. J. N. Galloway et al., Bioscience 53, 341 (2003).

21. V. Smil, Enriching the Earth: Fritz Haber, Carl Bosch and the Transformation of World Food Production (MIT Press, Cambridge, MA, 2001).

22. S. P. Seitzinger et al., Ecol. Appl. 16, 2064 (2006)

23. E. W. Boyer et al., Global Biogeochem. Cycles 20 GB1S91 (2006).

24. S. P. Seitzinger, J. A. Harrison, E. Dumont, A. H. W. Beusen, A. F. Bouwman, Global Biogeochem. Cycles 19, GB4S01 (2005).

25. R. W. Howarth et al., Biogeochemistry 79, 163 (2006).

26. Intergovernmental Panel on Climate Change, Working Group I Report: The Physical Science Basis (Cambridge Univ. Press, Cambridge, 2007).

27. B. A. Hungate, ]. S. Dukes, M. R. Shaw, Y. Q. Luo, C. B. Field, Science 302, 1512 (2003).

28. N. Gruber, ]. N. Galloway, Nature 451, 293 (2008).

29. S. P. Long, E. A. Ainsworth, A. D. B. Leakey, ]. Nosberger, D. R. Ort, Science 312, 1918 (2006).

30. Z. Zhu, Z. Xiong, G. Xing, Sci. China C Life Sci. 48, 729 (2005).

31. L. B. S. L. Lara et al., Atmos. Environ. 35, 4937 (2001).

32. C. J. Stevens, N. B. Dise, ]. O. Mountford, D. ]. Gowing, Science 303, 1876 (2004).

33. G. K. Phoenix et al., Global Change Biol. 12, 470 (2006).

34. P. A. Matson, W. H. McDowell, A. R. Townsend, P. M. Vitousek, Biogeochemistry 46, 67 (1999).

35. M. Volk, P. Bungener, F. Contat, M. Montani, J. Fuhrer, Global Change Biol. 12, 74 (2006).

36. M. H. Ward et al., Environ. Health Perspect. 113, 1607 (2005).

37. V. J. McKenzie, A. R. Townsend, EcoHealth 4, 384 (2007).

38. P. C. O. Trivelin, M. W. de Oliveira, A. C. Vitti, G. J. D. Gava, ]. A. Bendassolli, Pesqui. Agropecu. Bras. 37, 193 (2002)

39. P. ]. Crutzen, A. R. Mosier, K. A. Smith, W. Winiwarter Atmos. Chem. Phys. 8, 389 (2008).

40. R. W. Howarth et al. Millennium Ecosystem Assessment (Island Press, Washington, DC, 2005), chap. 9.

41. ]. W. Erisman, Bioscience 54, 286 (2004).

42. United Nations Environment Programme and Woods Hole Research Center, Paris, Reactive Nitrogen in the Environment: Too Much or Too Little of a Good Thing (2007), Fig. 3.

43. We appreciate the comments and assistance of M. Burke, ]. Cofala, K. Cassman, E. Davidson, F. Dentener, D. Kramer, A. Mosier, O. Oenema, P. Wiberg, and the International Fertilizer Industry Association on portions of this paper. We appreciate the editorial assistance of $\mathbf{M}$. J. Gore. This paper is a contribution to the International Nitrogen Initiative (www.initrogen.org) (jointly sponsored by Scientific Committee on Problems of the Environment and International Geosphere-Biosphere Programme), with special reference to the Fourth International Nitrogen Conference held in Brazil in October 2007. This paper is also a contribution to the European projects NitroEurope IP (European Commission), Nitrogen in Europe (NinE, European Science Foundation), and European Cooperation in the field of Scientific and Technical Research (COST) Action 729.

\section{Supporting Online Material}

www.sciencemag.org/cgi/content/full/320/5878/889/DC1

SOM Text

References

10.1126/science. 1136674 


\section{Science \\ МIAAAS}

\section{Supporting Online Material for}

\section{Transformation of the Nitrogen Cycle: Recent Trends, Questions, and Potential Solutions}

James N. Galloway,* Alan R. Townsend, Jan Willem Erisman, Mateete Bekunda, Zucong Cai, John R. Freney, Luiz A. Martinelli, Sybil P. Seitzinger, Mark A. Sutton

*To whom correspondence should be addressed. E-mail: jng@virginia.edu

Published 16 May 2008, Science 320, 889 (2008)

DOI: $10.1126 /$ science. 1136674

This PDF file includes:

SOM Text

References 


\section{Expansion of Discussion on Interactions of $\mathbf{N}$ and $\mathbf{C}$ in Terrestrial Ecosystems}

The latest IPCC report (S1) undertook the most comprehensive assessment of Nr-climate interactions to date, but several critical components remain uncertain. The potential response of the C cycle offers a good example. Although earlier syntheses based on ${ }^{15} \mathrm{~N}$ additions (S2) and modeled extensions of $\mathrm{N}$ budgets had suggested only a modest effect of $\mathrm{N}$ deposition on net forest $\mathrm{C}$ uptake, a recent synthesis of eddy flux data from northern hemisphere forests concluded that elevated $\mathrm{N}$ deposition is creating a sizable $\mathrm{C}$ sink (S3). This finding is currently a matter of hot debate, as a major synthesis of European forest inventory data (S4) and a re-analysis of the Magnani et al. dataset (S5) both imply a C:N response that is an order of magnitude smaller than that claimed. In addition, even if an $\mathrm{N}$-stimulated C sink is large, its future persistence is debatable, both because of progressive alleviation of $\mathrm{N}$ limitation, and because future increases in $\mathrm{N}$ deposition will be most pronounced in equatorial regions where $\mathrm{N}$ limitation is thought to be less widespread (S6). 


\section{Background Details on Use of Interventions to Decrease Nr Loss to Environment}

This material expands on the four intervention points mentioned in the paper's text and identified in Figure 3.

The first intervention point involves fossil fuel combustion. Using maximum feasible reductions, $\mathrm{Nr}$ creation during fossil fuel combustion can be decreased by about $30 \%$ of its current level (S7). The barriers to such a decrease are primarily financial, as the scientific, engineering and policy instruments are well developed. Utilizing this available technology, Nr creation from fossil fuel combustion would decrease from 25 Tg $\mathrm{N} \mathrm{yr}^{-1}$ to $\sim 7$ Tg $\mathrm{N} \mathrm{yr}^{-1}$.

The second intervention point is to increase the $\mathrm{N}$ use efficiency (NUE) of crop production. Cassman and colleagues estimate that there will be a $38 \%$ increase in global cereal demand by 2025. Compared to continuation of current trends, they project that this demand can be met with a 30\% decrease in $\mathrm{N}$ fertilizer application to cereals if the decline in cereal harvest area (-0.33\% $\mathrm{yr}^{-1}$ over 20 years) is halted and the crop yield response to applied $\mathrm{N}$ is increased by $20 \%$ (S8). This ‘intervention’ would reduce the

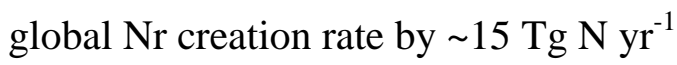

Third, improving the genetic potential of the herd, animal feeding strategies and manure management would decrease $\mathrm{N}$ losses to the environment. It is estimated that improved animal feeding strategies in EU-27 could decrease by 2020 the total $\mathrm{N}$ excretion by $\sim 13 \%$ and total $\mathrm{N}$ losses from animal manure by $\sim 11 \%$. A combination of 
improved animal feeding and low-emission techniques could decrease by 2020 total $\mathrm{N}$ losses from animal manure in EU-27 by 30\%. Extending this to the world while considering the diversity in herd management, animal feeding and animal manure management, would result in a decrease of $\sim 10-20 \mathrm{Tg}$ lost to the environment (S9). Animal production systems are highly conducive to releasing $\mathrm{Nr}$ to the environment, so eating less meat would both substantially decrease $\mathrm{Nr}$ losses while having potential health benefits (S10)

The fourth intervention point involves sewage treatment. Each year, the global population produces $\sim 20 \mathrm{Tg} \mathrm{N}$ in human waste of which $<1 \%$ undergoes treatment that will convert it to $\mathrm{N}_{2}$ (generally tertiary treatment). Even if only half of the 3.2 billion people who live in an urban environment had access to the required level of sewage treatment, this would result in $5 \mathrm{Tg} \mathrm{N}$ being converted to $\mathrm{N}_{2}$.

\section{Supplemental Material References}

S1. Intergovernmental Panel on Climate Change. Working Group I Report: The Physical Science Basis. (Cambridge Univ. Press, Cambridge, UK, 2007).

S2. K.J. Nadelhoffer et al., Nature 398, 145-148 (1999).

S3. F. Magnani et al., Nature 447, 848-850 (2007).

S4. W. De Vries et al., Nature 454, E1-E3 (2008). 
S5. M. A. Sutton et al., Global Change Biology: accepted (2008).

S6. P. A. Matson, W. H. McDowell, A. R. Townsend, P. M. Vitousek,

Biogeochemistry 46, 67-83 (1999).

S7. J. Cofala et al., Atmospheric Environment 41, 8486-8499 (2007).

S8. A. Dobermann \& K. G. Cassman. Science in China, Series C. Life Sciences

(Special Issue) 48, 745-758 (2005).

S9. O. Oenema \& S. Tamminga. Science in China, Series C. Life Sciences (Special Issue)48, 871-887 (2005).

S10. V. Smil, Population and Development Review 28, 599-639 (2002). 